циирровых карт и планов, обработки геодезических измерений и подготовки землеустроительной документации Delta/Digitals.

Ключевые слова: земельный участок, агропроизводственные группь грунтов, балль бонитета, межи земельного участка.

\title{
EXPERT APPROACH TO DIVISION OF LAND PLOTS IN ACCORD WITH CO-OWNER SHARES
}

Taranets T. A.

This article considers the issue of determining possibility and procedure for division of land plots (shares) of different ownership forms and their use by physical and legal persons while performing forensic examinations and expert research. Normative legal acts regulating issues of establishing the boundary and exploitation of land plots (shares) are presented. Analysis of questions of forensic land technical examination and expert researches concerning the possibility of performing divisions of land plots (shares) is given. At that it is indicated that while performing research on division of land plots (shares), a forensic expert should take into account that the physical size of a plot (share) does not coincide with its size in the conditional cadastral hectares, all the land plots (shares) of farms (enterprises) have the same value and size in conditional cadastral hectares; the physical size of plots (shares) depends on soil (ground) quality. Soil (ground) quality is determined by quality of locality score; soils of the same name holding have the same quality of locality score throughout natural and agricultural area. At the same time, the portions size of land plots (shares) of co-owners is calculated in proportion to their shares in the ownership of the land plot (share). Conditional portion size of land plot (share) of co-owner is defined as the sum of the areas of agricultural production groups of grounds located on this part of share, in qualitative terms, which is calculated by the method of approximation to its part in the "average portion" of the share per holding (enterprise). This calculation method can be performed using specialized software such as a computer program for creating digital maps and plans, processing geodetic measurements and preparing land use documentation Delta/Digitals.

Keywords: land plot, agro production ground groups, quality of locality scores, boundaries of the land plot.

DOI: https://doi.org/10.32353/khrife.2018.53

УДК 343.98

P. E. Мирошниченко, судовий експерт Харківського НДІСЕ

E-mail: miroshnichenko_hniise@ukr.net,

O. О. Мсшков, науковй співробітник

Харківського НДІСЕ

\section{МЕТОДОЛОГІЧНІ ПІДХОДИ ДО ЕКСПЕРТНОГО ДОСЛІДЖЕННЯ З РОЗРАХУНКУ ШКОДИ, ЗУМОВЛЕНОЇ ЗАСМІЧЕННЯМ ЗЕМЕЛЬНИХ РЕСУРСІВ}

(науково-методична стаття)

Розглянуто методологічні підходи до експертного дослідження розрахунку шкоди, зумовленої засміченням земельних ресурсів.

(C) Мирошниченко Р. Е., Мєшков О. О., 2018 
Ключові слова: судова інженерно-екологічна експертиза, засмічення земель, природоохоронне законодавство, відходи.

Визначення шкоди, зумовленої засміченням земельних ресурсів, становить значну частку в загальному обсягу екологічних правопорушень, що розслідуються та розглядаються судами в Україні, а їх розслідування $\epsilon$ найбільш складними в цій категорії.

Випадки засмічення земель належать до одних із найбільш поширених екологічних правопорушень. Більшість збитків за засмічення земельних ресурсів визначаються великими сумами, які за Кримінальним кодексом України розглядаються як тяжкі або особливо тяжкі наслідки порушень природоохоронного законодавства. За такі злочини передбачено кримінальну відповідальність. Здебільшого відшкодування збитків здійснюється за судовими рішеннями.

Згідно з календарним планом Мін'юсту України на 2017 р. у ХНДІСЕ було розроблено «Комплексну методику експертного визначення шкоди, зумовленої засміченням земельних ресурсів» ${ }^{1}$ (далі - Комплексна методика), яка визначає основні положення порядку проведення комплексних інженерно-екологічних та економічних досліджень щодо визначення шкоди, зумовленої засміченням земельних ресурсів. Актуальність роботи пов'язана зі зростанням потреб у вирішенні питань, що ставляться експертам органами досудового розслідування, судового слідства, організаціями та громадянами щодо визначення шкоди, зумовленої засміченням земельних ресурсів.

Із точки зору правового механізму визначення шкоди, зумовленої засміченням земельних ресурсів, базується на галузевій «Методиці визначення розмірів шкоди, зумовленої забрудненням і засміченням земельних ресурсів через порушення природоохоронного законодавства $)^{2}$ (далі - Методика). Невиконання законодавства про охорону та раціональне використання земельних ресурсів, що спричинили засмічення земель, визначаються відповідно до зазначеного документа. За галузевою Методикою визначаються також розміри відшкодування збитків, понесених державою внаслідок такого засмічення. Галузева Методика застосовується в разі невиконання вимог законодавства, виявлених при державному нагляді (контролі) господарської діяльності щодо дотримання суб'єктами господарювання природоохоронного законодавства (за Законом України «Про основні засади державного нагляду (контролю) у сфері господарської діяльності» ${ }^{3}$ ). Працівники Державної екологічної інспекції України (ДЕІ) використовують

1 Комплексна методика експертного визначення шкоди, зумовленої засміченням земельних ресурсів: звіт про НДР/ХНДІСЕ; І. П. Крайнов та ін. № ДР $0116 U 0038752017$. Харків, 2017. 20 c.

2 Методика визначення розмірів шкоди, зумовленої забрудненням і засміченням земельних ресурсів через порушення природоохоронного законодавства, затв. наказом Міністерства охорони навколишнього природного середовища від 27.10.1997 № 171, зі змінами (у редакції наказу Мінприроди від 04.04.2007 № 149). URL: http://zakon3. rada.gov.ua/laws/show/z0285-98.

Про основні засади державного нагляду (контролю) у сфері господарської діяльності : Закон України від 05.04.2007 № 877-V. URL: http://zakon3.rada.gov.ua/ laws/show/877-16. 
галузеву Методику для розрахунку розмірів шкоди, зумовленої забрудненням і засміченням земельних ресурсів різних категорій.

Найбільш відомими й поширеними 3 випадків недотримання вимог законодавства $є$ ті, що зафіксовано в документах перевірок органів державного контролю (Державної екологічної інспекції України, Міністерства охорони здоров'я України), що стали предметом досудового розслідування правовоохоронних органів, розгляду в судах усіх інстанцій у справах з усіх форм судочинства (адміністративного, господарського, кримінального, цивільного, про адміністративні правопорушення).

У Комплексній методиці запропоновано враховувати при експертному дослідженні розрахунку шкоди від засмічення земель такі етапи:

- перевірка умов застосування розрахунку;

- перевірка правильності вихідних даних, прийнятих для розрахунку;

— перевірка формальної та арифметичної правильності розрахунку;

— загальний висновок щодо правильності розрахунку, виконаного ДЕІ.

Щодо перевірки умов застосування розрахунку. Умови застосування розрахунку розміру шкоди, завданої внаслідок засмічення земель, базуються на таких положеннях:

- методика застосовується в ході встановлення розмірів шкоди від забруднення (засмічення) земель будь-якого цільового призначення, що сталося внаслідок несанкціонованих (непередбачених проектами, дозволами) скидів (викидів) речовин, сполук і матеріалів, через порушення норм екологічної безпеки в разі зберігання, транспортування та проведення вантажнорозвантажувальних робіт, використання пестицидів і агрохімікатів, токсичних речовин, виробничих і побутових відходів; самовільного розміщення промислових, побутових та інших відходів;

- методика не поширюється на визначення розмірів шкоди, яка завдана земельним ресурсам унаслідок їх радіоактивного чи бактеріального забруднення;

- при виявленні засмічення визначаються на місці обсяги засмічення відходами та інші показники, які необхідні для визначення розмірів шкоди;

- розміри шкоди обчислюються уповноваженими особами, що здійснюють державний контроль за додержанням вимог природоохоронного законодавства, на основі актів перевірок, протоколів про адміністративне правопорушення та інших матеріалів, що підтверджують факт засмічення земель, протягом шести місяців із дня виявлення порушення;

- основою розрахунків розміру шкоди від засмічення земель є нормативна грошова оцінка земельної ділянки, що засмічена;

- відходи, що спричинили засмічення земельної ділянки, класифікуються за 4 класами небезпеки згідно з чинними нормативними документами у сфері поводження 3 відходами (додаток 5 Методики)

- віднесення відходів, що спричинили засмічення земельної ділянки, до категорії небезпечних (токсичних) відходів здійснюється відповідно до чинних нормативних документів у сфері поводження з відходами, затверджених у встановленому порядку, переліків небезпечних (токсичних) відходів тощо.

1 Методика визначення розмірів шкоди... 
Щодо перевірки правильності вихідних даних, прийнятих для розрахун$\kappa y$. Розмір шкоди внаслідок засмічення земель визначається за формулою 6 Методики.

$$
\mathrm{P}_{\text {шз }}=\mathrm{A} \times \mathrm{5} \times \Gamma_{\text {оз }} \times \Pi_{\text {дз }} \times \mathrm{K}_{33} \times \mathrm{K}_{\text {нв }} \times \mathrm{K}_{\text {ег }},
$$

де $\mathrm{P}_{\text {шз }}$ - розмір шкоди від засмічення земель, грн; А - питомі витрати на ліквідацію наслідків засмічення земельної ділянки; Б - коефіцієнт перерахунку; $\Gamma_{\text {оз }}$ - нормативна грошова оцінка земельної ділянки, що зазнала за-

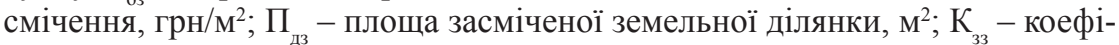
цієнт засмічення земельної ділянки, що характеризує ступінь засмічення іiі відходами; $\mathrm{K}_{\text {нв }}$ - коефіцієнт небезпеки відходів; $\mathrm{K}_{\text {ег }}$ - коефіцієнт екологогосподарського значення земель.

Форма розрахунку наведена в додатку 8 , приклад розрахунку - у додатку 11 Методики ${ }^{1}$.

Перевірка здійснюється за такою номенклатурою та показниками:

- площа засміченої ділянки, м $^{2}\left(\Pi_{\text {дз }}\right)$, визначається за актом про засмічення земель і за матеріалами спеціальних вишукувань;

- об'єм відходів $\left(\mathrm{м}^{3}\right)$, що спричинили засмічення, установлюють за об'ємними характеристиками цього засмічення як добуток площі засмічення земельної ділянки на товщину шару цих відходів. Товщину шару відходів ділянки визначають вимірюванням;

— питомі витрати на ліквідацію наслідків засмічення (А), величина яких складає 0,5 ;

— коефіцієнт перерахунку (Б), що при засміченні земельної ділянки побутовими, промисловими та іншими відходами дорівнює 10, а небезпечними (токсичними) відходами - 100;

- нормативна грошова оцінка земельної ділянки (проіндексована), грн/м² $\left(\Gamma_{\text {оз }}\right)$ визначається за довідкою територіального органу Держкомзему;

— коефіцієнт засмічення земельної ділянки $\left(\mathrm{K}_{33}\right)$ визначається за додатком 6 Методики; тодики;

- коефіцієнт небезпеки відходів $\left(\mathrm{K}_{\mathrm{Hв}}\right)$ визначається за додатком 5 Ме-

- коефіцієнт еколого-господарського значення земель $\left(\mathrm{K}_{\mathrm{er}}\right)$ визначається за додатком 2 Методики;

- розмір шкоди, грн $\left(\mathrm{P}_{\text {шз }}\right)$, здійснюється за відповідною формулою 6 Методики.

Згідно з підп. 5.6.1 Методики грошова оцінка земель, по яких не проведено її визначення, здійснюється за підп. 4.7.1 цієї Методики. Згідно з підп. 5.6.2 Методики розрахована за підп. 4.7.1 цієї Методики грошова оцінка використовується у формулі (1) замість нормативної грошової оцінки земельної ділянки $\left(\Gamma_{\text {оз }}\right)$.

\footnotetext{
1 Методика визначення розмірів шкоди...
} 
Значення коефіцієнта засмічення земельної ділянки $\left(\mathrm{K}_{33}\right)$ приймається за ступенем ії засмічення, визначеного залежно від об’єму відходів згідно $з$ додатком 6 Методики ${ }^{1}$.

Для земель, що засмічені багатотоннажними (>10 тис. т) відходами гірничодобувної промисловості, коефіцієнт засмічення земельної ділянки $\left(\mathrm{K}_{33}\right)$ приймається рівним 1,0 .

Значення коефіцієнта еколого-господарського значення земель $\left(\mathrm{K}_{\mathrm{er}}\right)$ приймається відповідно до категорії земель, що зазнали засмічення, або їх статусу як таких, що підлягають особливій охороні, згідно 3 додатком 2 Методики. Якщо за шкалою еколого-господарського значення земель (додаток 2 Методики) земельна ділянка, що зазнала засмічення, може бути класифікована за декількома категоріями земель чи особливостями охорони, для розрахунків обирається коефіцієнт еколого-господарського значення земель $\left(\mathrm{K}_{\text {er }}\right)$ з максимальним значенням серед відповідних коефіцієнтів.

Щодо перевірки формальної та арифметичної правильності розрахунку.

Зазначена перевірка стосується відповідності форми виконання розрахунку, установленій у Методиці, а також лише правильності (коректності) виконання арифметичних дій за відповідною формулою 6 (розмір шкоди внаслідок засмічення земель) п. 5 Методики².

Про загальний висновок щодо правильності розрахунку, виконаного ДЕІ, слід зазначити таке.

Загальний розрахунок уключає (поєднує) результати окремих розрахунків для кожної засміченої земельної ділянки, на підставі чого робиться загальний висновок про підтвердження результатів розрахунку, виконаного ДЕІ. Загальний висновок стосується розрахунку сумарного збитку за засмічення земельних ділянок відходами, виконаного ДЕІ в рамках планової/ позапланової перевірки суб'єкта господарської діяльності.

Аналіз експертної практики використання Методики свідчить про іiї низький арбітражний ефект, адже значна частина висунутих винуватцям позовів про відшкодування збитків або звинувачень не одержують задоволення в судових органах. Під арбітражним ефектом розуміють підтверджене арбітражним органом порушення вимог екологічного законодавства, що встановлено державним екологічним контролем ${ }^{3}$ Найбільшою мірою це стосується великих підприємств, які мають власні юридичні підрозділи. Через відсутність об'єктивних експертних висновків держава втрачає значні суми відшкодування збитків (помилка першого роду - правопорушення насправді мало місце, але не доведено в суді). 3 іншого боку, при помилкових позовах землекористувачі несуть невиправдані втрати (помилка другого роду - правопорушення насправді не було, але позов судом задоволено).

3 урахуванням викладеного розроблена в Харківському НДІСЕ Комплексна методика дає можливість одержати коректні з правової точки зору,

Методика визначення розмірів шкоди...

Там само.

Уберман В. І., Васьковеиьь Л. А. Арбітражний ефект екологічного контролю: концепція, критерії, приклади визначення. URL: http://vestnik.pp.ua/Browse ByAuthorHtml/1808/. 
повні, об' єктивні, науково, технічно й економічно обгрунтовані відповіді на питання, що стосуються розрахунку розміру шкоди, зумовленої засміченням земельних ресурсів.

\title{
МЕТОДОЛОГИЧЕСКИЕ ПОДХОДЫ К ЭКСПЕРТНОМУ ИССЛЕДОВАНИЮ РАСЧЕТА УЩЕРБА, ОБУСЛОВЛЕННОГО ЗАСОРЕНИЕМ ЗЕМЕЛЬНЫХ РЕСУРСОВ
}

\author{
Мирошниченко Р. Э., Мешков О. О.
}

Определение ущерба, обусловленного засорением земельных ресурсов, составляет значительную долю в общем объеме экологических правонарушений, которые рассматриваются судами в Украине, а их расследования являются наиболее сложными в этой категории. Большинство убытков от засорения земельных ресурсов определяются значительными суммами, которые по Уголовному кодексу Украинь рассматриваются как тяжкие или особо тяжкие последствия нарушений природоохранного законодательства. С точки зрения правового механизма определение ущерба, обусловленного засорением земельных ресурсов, базируется на отраслевой Методике определения размеров ущерба, обусловленного загрязнением и засорением земельных ресурсов через нарушение природоохранного законодательства, утвержденная приказом Министерства охраны окружающей природной среды № 171 от 27.10.1997 (с изменениями). Невыполнение законодательства об охране и рациональном использовании земельных ресурсов, повлекшее засорение земель, определяется в соответствии с этой Методикой. Методика применяется в случае нарушений, выявленных при государственном надзоре (контроле) хозяйственной деятельности по соблюдению субъектами хозяйствования природоохранного (земельного) законодательства (по закону Украинь «Об основных принципах государственного надзора (контроля) в сфере хозяйственной деятельности»). Работники Государственной экологической инспекиии Украины используют Методику, в частности, для расчетов размеров возмещзения ущеерба, причиненного государству в результате засорения земель. Анализ экспертной практики использования Методики свидетельствует о ее низком арбитражном эффекте, поскольку значительная часть выдвинутых должникам исков о возмещении убытков или обвинений не удовлетворяются судебными органами. Разработанная в Харьковском НИИСЭ Комплексная методика дает возможность получить корректные с правовой точки зрения, полные, объективные, научно, технически и экономически обоснованные ответы на вопросы, касающиеся расчетов ущерба, обусловленного засорением земельных ресурсов.

Ключевые слова: судебная инженерно-экологическая экспертиза, засорение земель, природоохранное законодательство, отходы.

\section{METHODOLOGICAL APPROACHES TO EXPERT RESEARCH ON DAMAGE ESTIMATE RESULTING FROM LAND CLOGGING}

\section{Myroshnychenko R. E., Meshkov O. O.}

Definition of damage caused through land clogging constitutes a significant share in the total amount of environmental offenses that are considered by courts in Ukraine and their investigations are the most difficult in this category. Majority of losses from land 
clogging are determined as significant amounts considered according to the Criminal Code of Ukraine as grave or especially grave consequences of environmental legislation violations. From the point of view of legal mechanism, the definition of damage caused through clogging of land resources is based on the branch Methodology for determining the amount of damage caused through pollution and clogging land resources by means of violation of environmental legislation, approved by order of the Ministry of Ecology and Natural Resources No 171 from 27.10 .1997 (as amended). Failure to comply with legislation on the protection and rational use of land resources resulting in land clogging is determined according to this Methodology. This Methodology is applied in case of violations revealed during the state supervision (control) of economic activities to comply with environmental (land) legislation by economic entities (according to the Law of Ukraine "On the Main Principles of State Supervision (Control) in the Area of Commercial Activity”). Employees of the State Ecological Inspectorate of Ukraine use the Methodology in particular to calculate the amount of compensation for damage caused to the state as a result of land clogging. Analysis of an expert practice of using the Methodology demonstrates its low arbitrage effect, since a significant part of the claims brought forward to debtors for compensation of damages or charges are not satisfied by the judicial authorities. Comprehensive methodology developed at KhRIFE makes possible to obtain correct from a legal point of view, complete, objective, scientifically, technically and economically justified answers to questions related to the calculation of the damage caused through land clogging.

Keywords: forensic engineering and environmental examination, land clogging, environmental legislation, wastes. 